\title{
MINERAL SUPPLEMENTATION AND PRODUCTIVITY OF THE SHIITAKE MUSHROOM ON EUCALYPTUS LOGS
}

\author{
Elvio Cardoso Queiroz ${ }^{1 *}$; Regina Helena Marino ${ }^{1}$; Augusto Ferreira da Eira ${ }^{2}$ \\ ${ }^{1}$ UNESP/FCA - Depto. de Produção Vegetal - Defesa Fitossanitária. \\ ${ }^{2}$ UNESP/FCA - Depto. de Produção Vegetal, Módulo de Cogumelo, C.P. 237 - 18603-970 - Botucatu, SP - Brasil. \\ *Corresponding author <elvioqueiroz@fca.unesp.br>
}

\begin{abstract}
Brazilian reports on Shiitake mushroom [Lentinula edodes (Berkeley) Pegler] productivity grown on Eucalyptus saligna (Sm.) logs are optimistic. The current production on this kind of wood is, however, low and variable. Aiming at increasing Shiitake mushroom productivity, the present work studied interactions among three concentrations of mineral supplement and three Shiitake strains (Le 95/01, 96/17 and 96/18) grown on seventh cut eucalyptus logs. Mineral fertilization was carried out when the logs were submerged in water to induce fruiting bodies, using the following saline concentrations: zero (no fertilizers added), $0.05 \%$ (equivalent to $0.35 \mathrm{~g} \mathrm{~L}^{-1}$ of ammonium sulfate with $18 \%$ nitrogen and $0.15 \mathrm{~g} \mathrm{~L}^{-1}$ of superphosphate with $34 \%$ phosphorus) and $0.50 \%$. Fertilization of the Le $95 / 01$ strain increased productivity, but logs inoculated with the Le $96 / 17$ strain were more productive only at $0.05 \%$ concentration while in the Le 96/18 strain, mineral supplementation decreased in productivity. The radial growth of these Shiitake strains (in sawdust-agar medium and with the same saline concentrations used in the log experiment) showed that all strains reacted positively to fertilization and that positive results for the Le 95/01 strain and negative results for Le 96/18 on eucalyptus logs are due to the natural higher competitiveness of the first Le 95/01 in relation to the latter Le 96/18 strain. Mineral fertilization increases the productivity provided that the logs are well colonized by Shiitake mushrooms.
\end{abstract}

Key words: Lentinula edodes, nitrogen, phosphorus

\section{SUPLEMENTAÇÃO MINERAL E PRODUTIVIDADE DE COGUMELO SHIITAKE EM TOROS DE EUCALIPTO}

\begin{abstract}
RESUMO: As estimativas de produtividade do cogumelo Shiitake no Brasil em eucalipto são otimistas mas, na prática, a produção nessa madeira é baixa e inconstante. Visando aumentar a produtividade do Shiitake, estudaram-se as interações entre doses de suplementação mineral, em relação a três linhagens do cogumelo (Le 95/01, 96/17 e 96/18) inoculadas em toros de eucalipto de sétimo corte. A suplementação mineral foi realizada na água de imersão dos toros, no momento de cada indução da frutificação, nas seguintes concentrações: $0,00 \%$ (sem adição de suplementos), $0,05 \%$ (sulfato de amônio, com $18 \%$ de nitrogênio solúvel em água, na dosagem $0,35 \mathrm{~g} \mathrm{~L}^{-1}$ e superfosfato triplo, com $34 \%$ de fósforo solúvel em água, na dosagem $0,15 \mathrm{~g} \mathrm{~L}^{-1}$ ) e na concentração $0,50 \%$ (correspondendo à dosagem dez vezes maior que a anterior). Houve aumento de produtividade na linhagem Le 95/01. Toros inoculados com Le 96/17 foram mais produtivos apenas na dose de $0,05 \%$ e, para a linhagem Le $96 / 18$ a produtividade diminuiu com a suplementação. A avaliação do crescimento radial com essas linhagens (meio de cultura de serragem com as mesmas concentrações salinas utilizadas no experimento em toros) evidenciou que todas responderam positivamente à suplementação e que, as respostas positivas da linhagem Le 95/01 e negativa da Le 96/18 obtidas no cultivo em toros de eucalipto de sétimo corte, são reflexos da maior competitividade da primeira linhagem em relação à segunda. A suplementação aumenta a produtividade desde que os toros estejam bem colonizados pelo Shiitake.
\end{abstract}

Palavras-chave: Lentinula edodes, nitrogênio, fósforo

\section{INTRODUCTION}

The Shiitake mushroom, in Brazil, has been cultivated almost exclusively on eucalyptus logs due to their lower exigency in terms of cultivation installations and handling. On the other hand, there are frequent producer complaints regarding low and inconsistent yields which have caused many of them to abandon their activities or find alternative cultivation on heat-treated particulate substrates such as axenic media.

The brazilian literature regarding production of Shiitake on eucalyptus logs is optimistic in that logs, 12 $\mathrm{cm}$ in diameter, produce up to $1.5 \mathrm{~kg}$ of fresh mushrooms per linear meter of $\log$ (Bononi et al., 1995; Eira \& Montini, 1997). This excessive of optimism, resulting from the lack of scientific background and from the ex- 
trapolation of data obtained in other countries using other types of wood, has included the generalization that cultivation of Shiitake on logs is low cost and has a rapid financial return. These extrapolations, however, do not support the fact that eucalyptus logs are not associated with uniformity in production (Montini, 1997; Andrade, 1999; Teixeira, 2000). Some logs (with mean diameter of $10 \mathrm{~cm}$ and length $1 \mathrm{~m}$ ) produced $660 \mathrm{~g}$ of fresh mushrooms per log in the first harvest but, others did not reach this productivity, as suggested in the literature (Montini, 1997). Shiitake productivity is related to climatic conditions and the interaction among lines and species of eucalyptus (Teixeira, 2000). The level of contamination of the $\operatorname{logs}$ is another factor that affects yield (Andrade, 1999).

In addition to sanitary problems in Shiitake cultivation, the eucalyptus, when cultivated in low-fertility soil, can produce a wood that is poor in nutrients, important for the development of Shiitake. Another important aspect is the number of eucalyptus cuts, since the older the cut, the poorer the wood, due to soil exhaustion in the course of conducting the forest (Barros, 1990).

The objective of this research was to evaluate mineral-supplementation interactions for the cultivation of the edible mushroom Shiitake, aiming to attenuate nutritional problems of eucalyptus wood, which has an impact on the yield of this mushroom.

\section{MATERIAL AND METHODS}

The experiments were conducted in Botucatu, SP, Brazil (2251' S, 48 $27^{\prime} \mathrm{W}$, altitude $786 \mathrm{~m}$ ).

\section{Lines and cultivation}

The inoculant or "seed" of L. edodes lines Le 95/ 01, Le 96/17 and Le 96/18followed the methodology described by Eira \& Montini (1997), as well as the cutting and inoculation of eucalyptus logs (7 to $12 \mathrm{~cm}$ in diameter and $100 \mathrm{~cm}$ long) of the seventh cut of a non-fertilized population of Itatinga, $\mathrm{SP}\left(23^{\circ} 02^{\prime} \mathrm{S}, 48^{\circ} 38^{\prime} \mathrm{W}\right.$, altitude $826 \mathrm{~m}$ ). Incubation conditions in a covered shed were $25 \pm 5^{\circ} \mathrm{C}$, with relative humidity varying between 60 and $95 \%$

\section{Mineral Supplementation}

Interactions of mineral supplementation (two rates and a control treatment) were evaluated for three lines of the Shiitake mushroom and, after six months of incubation, fruitification was stimulated artificially in immersion tanks of contents supplemented with minerals. Minerals were supplied, at the following levels: control treatment (certified without mineral supplementation); $0.05 \%$ supplementation (equivalent to $0.35 \mathrm{~g} \mathrm{~L}^{-1}$ of ammonium sulfate with $18 \%$ nitrogen and $0.15 \mathrm{~g} \mathrm{~L}^{-1}$ of triple superphosphate with $34 \%$ phosphorus) and $0.50 \%$.
For this procedure, together with the induction of mineral supplementation, the nutrients were dissolved in water and added to the immersion tank. Part of the volume was filled with cold water, calculated by approaching the initial temperature of $15 \pm 5^{\circ} \mathrm{C}$, until covering all the logs, which were then kept immersed for 18 hours. All logs were then transferred to a climatized chamber, with temperature alternating between $20 \pm 0.5^{\circ} \mathrm{C}$ and 25 $\pm 0.5^{\circ} \mathrm{C}$ and relative humidity between $80 \pm 2 \%$ and 95 $\pm 2 \%$, in cycles of 12 hours. The concentration of carbon dioxide gas was maintained between 900 and 1000 $\mu \mathrm{L} \mathrm{mL}{ }^{-1}$. The following production phases were induced by the same method after varying periods of inactivity for the logs: the second fruiting occurred 30 days after the first; the third, 45 days after the second and the final one 60 days after the third.

\section{Evaluation of productivity on logs}

Productivity is defined as the yield of wet biomass of mushroom (g) per $\mathrm{kg}$ of dry $\log$ in four accumulated production frutings. The dry mass of the logs was determined through the basic density of the wood, and the log's mean diameter and length.

The basic density of the wood is defined as the relation between the mass of an oven-dried sample and its displaced volume in water. This was determined with a hydrostatic balance (ABNT, 1979), to measure samples of 50 logs of virgin wood (non-degraded wood was used to evaluate the initial basic density, Dbi, in $\mathrm{t} \mathrm{m}^{-3}$ ). The mean diameter of the $\log$ was measured with a pachymeter (accuracy of $\pm 1 \mathrm{~mm}$ ), recording the diameter $\mathrm{D}(\mathrm{m})$, and the length $\mathrm{L}(\mathrm{m})$ of each log to measure the humid volume: Vtu $=\left(\pi \times(D / 2)^{2} \times L\right),\left(m^{3}\right)$.

With the wet volume of the logs, the mass of the initial dry log Mtsi $(\mathrm{kg})$ was calculated as: Mtsi $=$ Dbi $\mathrm{x}$ Vtu.

\section{Evaluation of radial growth}

An extract medium of log sawdust $\left(300 \mathrm{~g} \mathrm{~L}^{-1}\right)$ and agar $\left(15 \mathrm{~g} \mathrm{~L}^{-1}\right)$ was utilized to evaluate the radial growth of the same lines of the Shiitake on Petri dishes (Eira \& Montini, 1997). The sawdust was obtained from the same population of experimental trees, from recently-cut logs in the field. The extract was obtained from this dust by infusion in $1000 \mathrm{~mL}$ of boiling water for 30 minutes followed by filtration through cotton fabric resulting $800 \mathrm{~mL}$ of extract.

After filtration, mineral supplementation of the sawdust extract was made with the following treatments: control $0.00 \%$ (control without mineral supplementation); $0.05 \%$ supplementation (equivalent to $0.35 \mathrm{~g} \mathrm{~L}^{-1}$ of ammonium sulfate with $18 \%$ nitrogen and $0.15 \mathrm{~g} \mathrm{~L}^{-1}$ of triple superphosphate with $34 \%$ phosphorus) and $0.50 \%$ supplementation (rate ten times greater than the prior one). The $\mathrm{pH}$ of the culture medium was not corrected $(\mathrm{pH}=4.1)$ 
and the agar was partially sterilized in $200 \mathrm{~mL}$ of water. The Petri dishes were identical (disposable) and, the amount of base culture medium from the dust extract was $20 \pm 1 \mathrm{~mL}$ per plate, dosed by a volumetric pipette. Evaluation was made daily at the same hour to register the radial growth until the fungus mycelium reached approximately $0.5 \mathrm{~cm}$ from the edge of the dish.

\section{Chemical analysis of Shiitake}

In the final fruting of the experimental production on logs, mushroom samples from all treatments were submitted to a Weende-scheme chemical analysis. For determination of the $\mathrm{C} / \mathrm{N}$ ratio in the wood, samples were removed, with ten replicates, from the inoculated logs after the fourth fruiting, and from (non-degraded) virgin wood, according to the method described by Silva (1990).

\section{Statistical Methodology}

A $3 \times 3$ factorial experimental arrangement was used in a completely randomized design combining three lines and three levels of mineral supplementation, with 40 replicates (logs) per treatment. For productivity, nonparametric analysis of variance and the Kruskal-Wallis test were utilized. Whenever there were differences, the Student-Newman-Keuls (SNK) test was applied at 5\% probability. For mycelial growth, parametric analysis of variance was run using F-test, with data from the fifth day after inoculation. Means were compared using the Tukey Test at 5\%.

\section{RESULTS AND DISCUSSION}

For the first fruiting, productivity was negligible; even after six months of incubation only a few $\log s$ showed signs of colonization with spontaneous fruitification. This may be related to the substrate culture since the amount of nutrients in the logs from the seventh cutting did not allow for extensive colonization of the log by Shiitake, increasing the fruitification period in comparison to logs from the first or second cutting. The primordial induction period can vary as a function of climatic conditions and substrate culture (Przybylowicz \& Donogue, 1990; Montini, 1997).

For the second and third fruitings the accumulated mean productivities were low. Even so, the supplementation had positive effects on accumulated productivity of lines Le 95/01 and Le 96/17 and a negative effect upon line Le 96/18 (Figure 1). After four fruitings the accumulated mean productivity increased considerably (Figure 1), and significant interaction occurred between lines and rates of mineral supplementation. In other words, Le 95/01 was the line that responded best to mineral supplementation in contrast to Le 96/18 (Table 1).

Teixeira (2000), working with the lines Le 95/01 and Le 96/17 among others inoculated three eucalyptus species including E. saligna (derived from fertilized populations and trees of the first cutting) and obtained production prematurely beginning at the third month of

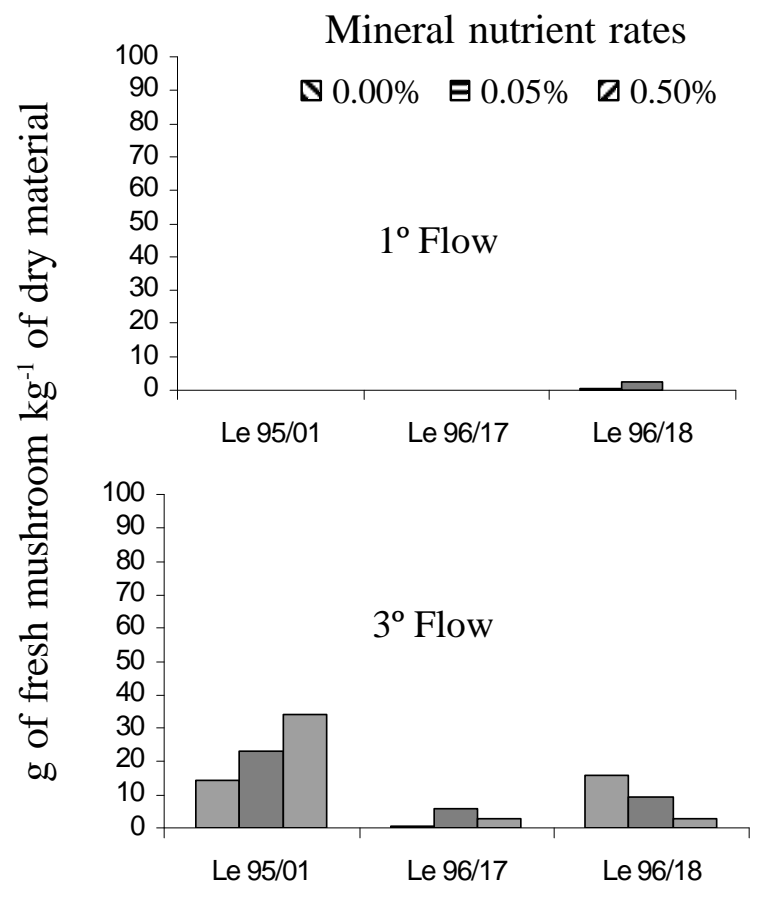

\section{Line}
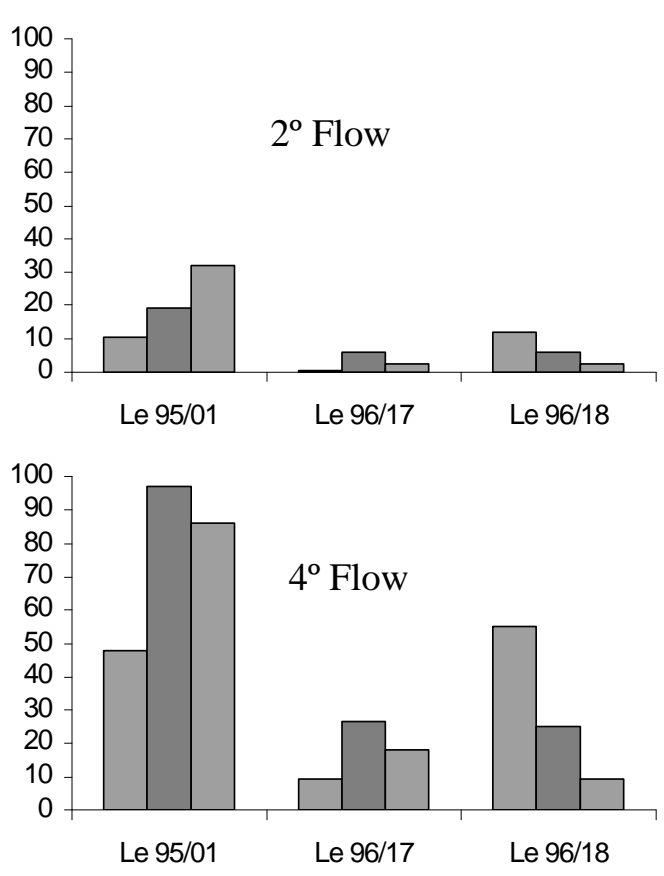

Figure 1 - Mean accumulated productivity of Lentinula edodes in logs of E. saligna supplemented with mineral nutrient for four fruitifications (mean of 40 replicates accumulated for each fruitification). 
incubation. This reinforces the hypothesis of late production, obtained in the present work, possibly due to the low nutrition level of the seventh cutting of eucalyptus cultivated on non-fertilized soil. On the other hand, part of the nutrients necessary for mushroom fruitification were partially incorporated in $\log$ s with mineral supplementation, but only line Le 95/01 increased productivity appreciably (Figure 1, Table 1). This suggests that the colonization of exhausted logs depends on the aggressivity of the line and its competitiveness with the ambient microbiota.

Another aspect to be addressed is the ideal time of repose between consecutive fruiting phases which, according to Przybylowicz \& Donogue (1990) and Eira \& Montini (1997) has to be 60 days, at the end of which the fungus will have had time to metabolize more nutrients and store energy for the next phase. In the present work, until the third fruiting these periods were less than 60 days, since reduction of the periods among production phases as a function of mineral supplementation was expected. Late production may have been due to the scarcity of nutrients in the logs (treatment without mineral supplemenation), associated with the time needed for mineral supplementation to be effective. Indeed this happened with line Le 95/01 since its productivity was greater only for the fourth fruiting (Figure 1, Table 1).

It was expected that the responses would be immediate with mineral supplementation in the immersion bath and, probably would have a cumulative effect. In fact with successive supplementations a direct $\mathrm{C} / \mathrm{N}$ relationship was observed in inoculated logs as compared to that of virgin wood (Figure 2), which can explain, in part, the productivity increase of the fourth fruiting. Shiitake cultivation on heat-treated enriched sawdust with sugarcane (Saccharum officinarum L.) bagass was studied by Montini (2001), who measured increased productivity for line Le 96/17 as a function of greater wheat meal enrichment of the sawdust, while for other lines this enrichment was harmful. However, the $\mathrm{C} / \mathrm{N}$ ratio is narrower $(15 / 1$

Table 1 - Cumulative productivity for four fruitifications of Lentinula edodes ("Shiitake") mushrooms on Eucalyptus saligna logs, for rates $0.00 \%, 0.05 \%$ and $0.50 \%$ of nitrogen and phosphate mineral supplementation (mean data of 40 replicates).

\begin{tabular}{lccc}
\hline & \multicolumn{4}{c}{ Supplementation rate (\%) } \\
\cline { 2 - 4 } Line & 0.00 & 0.05 & 0.50 \\
\hline & \multicolumn{4}{c}{$\mathrm{g}$ of fresh mushroom kg ${ }^{-1}$} & dry log \\
Le $95 / 01$ & $46.02 \mathrm{~b} / \mathrm{A}^{(1)}$ & $92.89 \mathrm{a} / \mathrm{A}$ & $84.65 \mathrm{a} / \mathrm{A}$ \\
Le $96 / 17$ & $0.00 \mathrm{a} / \mathrm{B}$ & $26.14 \mathrm{a} / \mathrm{B}$ & $0.00 \mathrm{a} / \mathrm{B}$ \\
Le $96 / 18$ & $51.16 \mathrm{a} / \mathrm{A}$ & $0.00 \mathrm{~b} / \mathrm{C}$ & $0.00 \mathrm{~b} / \mathrm{B}$ \\
\hline
\end{tabular}

${ }^{(1)}$ Same lower-case letters in each line and same upper-case letters in each column indicate no difference among means by the StudentNewman-Keuls test (5\%). to 20/1) for sawdust cultivation, in comparison to wooden logs, and high levels of nitrogen can reduce the fungal growth by lower degradation of substrate (Royse et al., 1985 and Fasidi \& Kadiri, 1993).

In the production phase of spawn culture, the $\mathrm{C} /$ $\mathrm{N}$ ratio can also affect mushroom productivity and quality (Tokimoto \& Kawai, 1975). This, however, does not explain the results obtained in this work since the additions of nitrogen to the logs were not sufficient to narrow the $\mathrm{C} / \mathrm{N}$ ratio at the levels utilized by Tokimoto \& Kawai (1975), to the point of inhibiting development and fructification of lines Le 96/17 and Le 96/18 (75 to 130/1 versus 15 and 20/1 from sawdust cultivation). The increase in supplementation with nitrogen and phosphorus in Le 95/ 01 resulted in greater productivity as compared to the control corroborating with the recommendations of Eira \& Montini (1997) for mineral supplementation of logs after the third fruiting. For line Le 96/18, however, the greater mineral supplementation resulted in reduced productivity, which appears contradictory at first (Figure 1). The mycelium growth kinetics of line Le 96/17, in one type of sterilized sawdust enriched with levels of wheat meal was studied by Regina (2001) who found a significant increase in growth ratio along with an increased quantity of wheat meal in the sawdust (source organic nitrogen).

Thus, to corroborate the hypothesis that under high $\mathrm{C} / \mathrm{N}$ ratios (150/1), mineral supplementation would gradually increase the growth of $L$. edodes, an experiment was set up to evaluate the radial growth of the three lines which had been inoculated in the logs (Figure 3 and Table 2). In this "in vitro" condition without antagonistic conditions of contaminants and in culture medium of sawdust extract, in other words with $\mathrm{C} / \mathrm{N}$ similar to the wooden logs, the radial growth of the three lines of Shiitake responded equally to the supplementation with nutrients.

To explain the response to mineral supplementation of lines Le 96/17 and Le 96/18 as compared to Le 95/01, it must be considered that the critical phase of log colonization occurred under adverse nutritional conditions

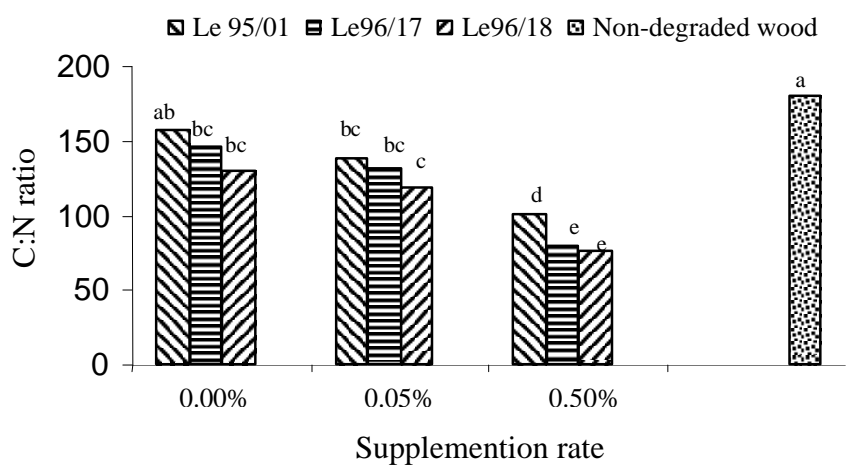

Figure 2 - C:N ratio of E. saligna wood colonized after four fruitification of Lentinula edodes and from nondegraded wood (mean of four samples composed of tem replicates). 
Table 2 - Mycelium radial growth on plates on the fifth day after incubation (mean of eight replications).

\begin{tabular}{lcccc}
\hline & \multicolumn{4}{c}{ Supplementation rate (\%) } \\
\cline { 2 - 5 } Treatment & 0.00 & 0.05 & 0.50 & mean \\
\hline & $-1.71 \mathrm{ab}^{(1)}$ & $5.23 \mathrm{ab}$ & $5.54 \mathrm{a}$ & $5.16 \mathrm{~A}^{(2)}$ \\
Le 95/01 & $4.20 \mathrm{c}$ & $4.71 \mathrm{~b}$ & $5.01 \mathrm{~b}$ & $4.64 \mathrm{~B}$ \\
Le 96/17 & $4.36 \mathrm{c}$ & $4.73 \mathrm{~b}$ & $5.64 \mathrm{a}$ & $4.91 \mathrm{~A}$ \\
\hline Le 96/18 & $4.42 \mathrm{~B}^{(3)}$ & $4.89 \mathrm{~A}$ & $5.4 \mathrm{~A}$ & \\
\hline $\begin{array}{l}\text { Mean } \\
\text { growth }\end{array}$ &
\end{tabular}

${ }^{(1)}$ Means followed by same lower-case letters do not differ (Tukey, $5 \%$ ) and represent means of interations between rate and line.

${ }^{(2)}$ Means followed by same upper-case letters do not differ (Tukey, $5 \%$ ) and represent means of each line, independent of rate.

${ }^{(3)}$ Means followed by same upper-case letters do not differ (Tukey, $5 \%$ ) and represent means of each rate, independent of line.

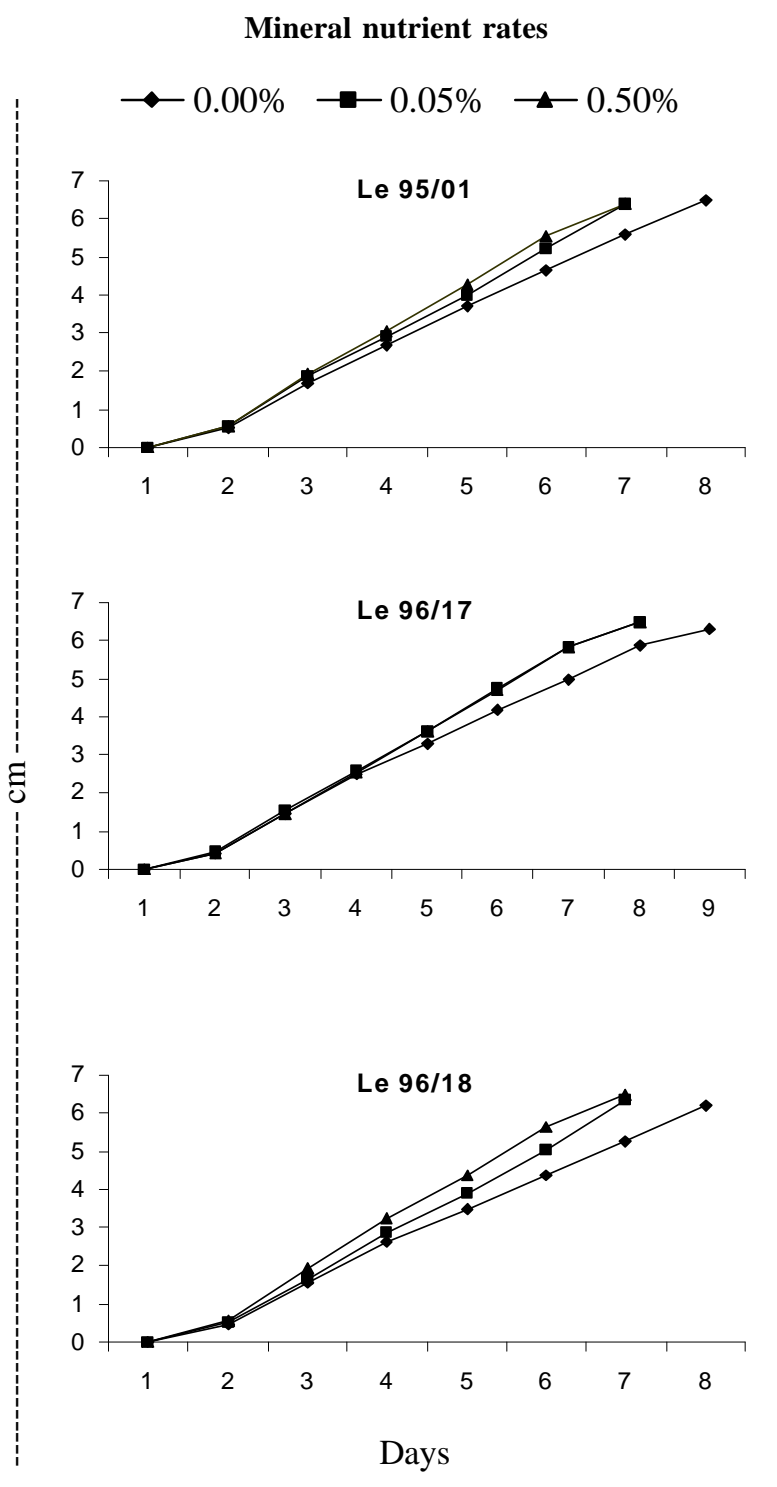

Figure 3 - Radial growth of Lentinula edodes (mean of eight replicates). (trees of the seventh cutting), and that minerals were supplied only with the first shock of immersion of the logs. This confirms the hypothesis that line Le 95/01, was more competitive during these initial conditions and, consequently, was favored by supplementation. In contrast, with the other two less competitive lines (Le 96/17 and Le 96/18), supplementation would have favored much more aggressive contaminants in these initial, adverse conditions and consequently harmed the Shiitake by establishing antagonistic relationships with the contaminants. The results from the experiment to evaluate radial growth of Shiitake ratified this hypothesis since under axenic laboratory conditions, all lines responded to mineral supplementation at two concentrations, $0.05 \%$ and $0.50 \%$, evidencing that the supplementation is beneficial for Shiitake development (Figure 3 and Table 2). In light of this, it is more probable that lines Le 96/17 and Le 96/ 18 were less competitive and that mineral supplementation favored, to a greater extent, the fungal competitors which, during incubation, colonized the logs most aggressively.

The contaminant microorganisms are wild fungi, better adapted to the substrate and, according to Przybylowicz \& Donoghue (1990), when the Shiitake undergoes stress during incubation, its capacity to resist contaminants and competitors is reduced, allowing for easy contamination of the log. Thus, from the elevated contaminant levels in the inoculated logs of lines Le 96/17 and $96 / 18$, it can be concluded that mineral supplementation aided the contaminants to a much greater extent than the Shiitake.

Many producers attribute the delay in fruitification and low productivity to the poor quality of the inoculant. However, the species of eucalyptus that was cultivated, the soil or the fertilizer used for eucalyptus forest are often unknown. Also unknown is the number of cuttings undergone by the trees since their planting, ignoring the importance of wood substrate in relation to productivity. This was evidenced in the present work, in which greater production occurred only in the fourth fruting, 363 days after inoculation of the logs. This long period is mainly due to the wood substrate (logs from the seventh cutting), nutritionally poor for Shiitake, but satisfactory for competitors. On the other hand it must be remembered that for commercial cultivation the inoculant can be contaminated or may have lost its fruitification properties.

Mineral supplementation increased the protein content of Shiitake (Figure 4 and Table 3), as a direct function of increasing rates of mineral supplementation. Given the higher mushroom protein content, it is probable that mineral supplementation also may alter (increase or diminish) nutraceutical compounds, such as those emphasized by Chang \& Miles (1984). 
Table 3 - Centesimal analysis of mushrooms by treatment (triplicate mean).

\begin{tabular}{lccccccc}
\hline Treatment & DM & CP & EE & Ash & CF & NFE & TDN \\
\hline Le 95/01 (0.00) & 92.32 & 20.10 & 3.14 & 4.22 & 11.30 & 61.24 \\
Le 95/01 (0.05) & 92.83 & 24.40 & 2.32 & 3.96 & 13.20 & 56.12 & 69.73 \\
Le 95/01 (0.50) & 93.63 & 26.36 & 2.81 & 3.93 & 13.98 & 52.92 & 69.91 \\
Le 96/17 (0.00) & 92.34 & 22.63 & 2.58 & 4.39 & 14.23 & 56.17 & 69.57 \\
Le 96/17 (0.05) & 93.19 & 26.59 & 2.48 & 4.02 & 12.17 & 54.74 & 69.91 \\
Le 96/17 (0.50) & 93.25 & 28.69 & 2.29 & 2.95 & 12.27 & 53.80 & 69.69 \\
Le 96/18 (0.00) & 90.12 & 22.10 & 2.67 & 4.64 & 13.57 & 57.08 & 70.02 \\
Le 96/18 (0.05) & 91.00 & 23.13 & 2.38 & 4.86 & 16.31 & 53.32 & 67.94 \\
Le 96/18 (0.50) & 91.24 & 26.42 & 2.60 & 4.40 & 12.89 & 53.69 & 69.48 \\
\hline
\end{tabular}

$\mathrm{DM}=$ Dry Material, $\mathrm{CP}=$ Crude Protein, $\mathrm{EE}=$ Ethereal Extract, Ashes $=$ Minerals, $\mathrm{CF}=$ Crude Fiber,

$\mathrm{NFE}=$ Non-free Extract, $\mathrm{TDN}=$ Total Digestive Nutrients

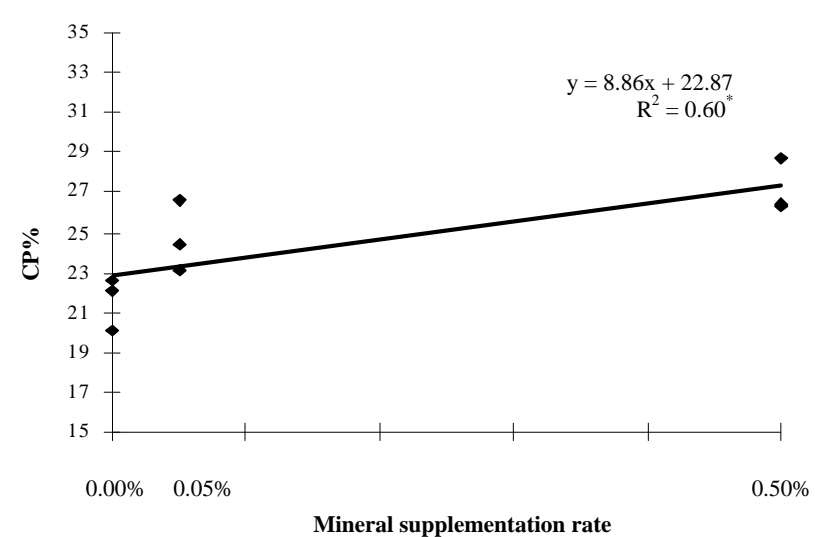

Figure 4 - Regression analysis of protein concentration of Shiitake mushrooms as a function of mineral supplementation.

\section{ACKNOWLEDGEMENTS}

To CAPES for fellowship, to FAPESP (Proc. 98/ 07726-5) for financial support, and Fundação Lucentis (Módulo de Cogumelos - UNESP/FCA Botucatu) for infrastructure.

\section{REFERENCES}

ANDRADE, A.A. Efeito de fungos contaminantes na produção de shiitake (Lentinula edodes (Berk) Pegler) em cepos de Eucalyptus saligna Sm. Botucatu: UNESP/FCA, 1999. 61p. (Dissertação - Mestrado).

ASSOCIAÇÃO BRASILEIRA DE NORMAS TÉCNICAS. NBR 11.419 Madeira- Método de determinação da densidade básica. Rio de Janeiro: ABNT, 1979. 2p.

BARROS, N.F. Relação solo-planta. Viçosa: Folha de Viçosa, 1990. 330p. BONONI, V.L.R.; CAPELARI, M.; TRUFEM, S.F.B.R. Cultivo de cogumelos comestíveis. São Paulo: Ícone, 1995. 206p.
CHANG, S.T.; MILES, P.G. A new look and cultivated mushrooms. Bioscience, v.34, p.358-362, 1984.

EIRA, A.F.; MONTINI, R.M.C. Manual teórico prático de cultivo do cogumelo Shiitake (Lentinula edodes (Berk.) Pegler). Botucatu Fundação de Estudos de Pesquisas Agrícolas e Florestais, 1997. 38p.

FASIDI, I.O.; KADIRI, M. Use of agricultural wastes for the cultivation of Lentinus submundus (Poluporales: Polyporacea) in Nigeria. Revista de Biologia Tropical, v.41, p.411-415, 1993.

MONTINI, R.M.C. Produtividade de shiitake (Lentinula edodes (Berk) Pegler), no primeiro choque de indução, em função de características das toras do Eucalyptus saligna Sm, variáveis do ambiente e período de incubação. Botucatu: UNESP/FCA, 1997. 61p. (Dissertação - Mestrado).

MONTINI, R.M.C. Efeito de linhagens e substratos no crescimento miceliano e na produtividade em cultivo axênico de shiitake (Lentinula edodes (Berk.) Pegler). Botucatu: UNESP/FCA, 2001. 104p. (Tese Doutorado).

PRZYBYLOWICZ, P.; DONOGHUE, J. Shiitake growers handbook. The art and science of mushroom cultivation. Dubuque: Kendall, 1990. 217p.

REGINA, M. Cinética do crescimento miceliano de Lentinula edodes (Berk.) Pegler em bagaço de cana-de-açúcar e serragem de eucalipto. Botucatu: UNESP/FCA, 2001. 87p. (Dissertação - Mestrado).

ROYSE, D.J.; SCHISLER, L.C.; DIEHLE, A. Shiitake mushroom consumption, production and cultivation. Interdisciplinary Science Reviews, v.10, p.329-335, 1985.

SILVA, D.J. Análises de alimentos (Métodos químicos e biológicos). 2.ed. Viçosa: UFV, 1990. 165p.

TEIXEIRA, E.M. Caracterização e avaliação de linhagens de shiitake (Lentinula edodes (Berk) Pegler) inoculadas em Eucalyptus grandis, E. urophila, E. saligna, cultivadas em clima cwa subtropical, em função da produtividade e qualidade dos basidiocarpos. Araraquara: UNESP/IQ, 2000. 149p. (Tese - Doutorado).

TOKIMOTO, K.; KAWAI, A. Nutritional aspects on fruit-body development in replacement culture of Lentinus edodes (Berk.) Sing. Report of the Tottori Mycological Institute, v.12, p.25-30, 1975.

Received November 18, 2002

Accepted March 26, 2004 